
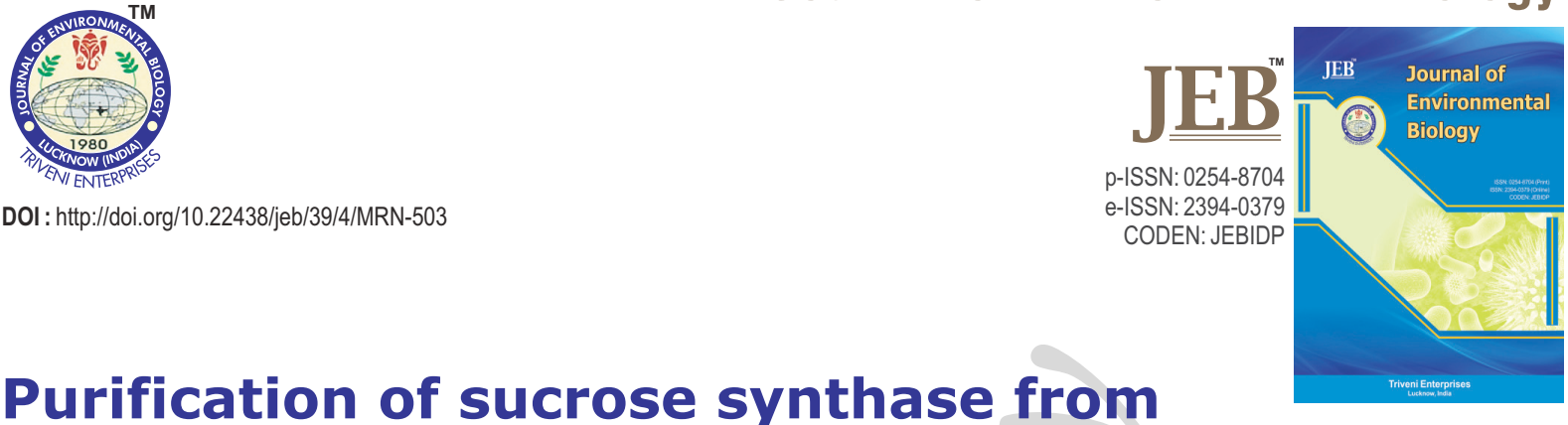

\title{
Purification of sucrose synthase from thermotolerant wheat grains and its characterization
}

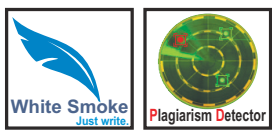

Authors Info

E. Verma, B. Sharma*, H.R. Singal and R. Munjal

Department of Chemistry and Biochemistry, Department of Genetics and Plant Breeding, CCS, Haryana Agricultural University, Hisar-125 004, India

*Corresponding Author Email : sharmabunty097@gmail.com

Key words

Characterization

Purification

Sucrose synthase

Thermotolerant

Wheat grains

Publication Info

Paper received : 02.11 .2016

Revised received : 14.07.2017

Re-revised received : 26.09 .2017

Accepted:07.11.2017

\section{Abstract}

Aim : Wheat is common and popular cereal with wide utilization and acceptability. High temperature stress drastically affects crop productivity and quality by disturbing sucrose metabolism. Hence, the aim of present investigation was to purify and characterize of sucrose synthase from thermotolerant wheat for various physico-chemico-kinetic properties.

Methodology : The immature grains of thermotolerant wheat $\mathrm{WH}-1021$ were used for purification of sucrose synthase by using traditional protein purification techniques viz. $\left(\mathrm{NH}_{4}\right)_{2} \mathrm{SO}_{4}$ fractionation, gel filtration through sephadex G-100 and DEAE-cellulose ion exchange chromatography. The purity was checked by native PAGE, while subunit by SDSPAGE.

Results : The enzyme was purified about 27 fold with approximately $37 \%$ recovery. The native enzyme had a molecular weight of $269 \mathrm{KDa}$ and subunit molecular weight was found to be $63 \mathrm{KDa}$, indicating that enzyme is a homotetramer. The purified enzyme exhibited optimum activity at $37^{\circ} \mathrm{C}$ with thermostablity upto $50^{\circ} \mathrm{C}$ and $\mathrm{pH} 6.5$. Sucrose synthase showed $K_{m}$ values of 14.28 and $1.18 \mathrm{mM}$ for sucrose and UDP, respectively. Its activity was inhibited by $\mathrm{Mn}^{2+}$ $(38.5 \%)$, while $\mathrm{NO}_{3}{ }_{3}$ stimulated the activity by $20.8 \%$ at $2 \mathrm{mM}$ concentration.

Interpretation : Among the various nucleotides tested, the enzyme was highly specific for UDP as substrate and NADP ${ }^{+}$ and G-6-P were found to be the potent inhibitors. The kinetic studies revealed that sucrose synthase catalyzed the sucrose degradation by ping-pong mechanism. The results of the present study would help in planning the strategies for increased wheat productivity without compromising the quality under stress conditions.
Purification and characterization of sucrose synthase from grains of thermotolerant wheat genotype $\mathrm{WH}-102$

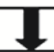

Tradition protein purification techniques viz. $\left(\mathrm{NH}_{4}\right)_{2} \mathrm{SO}_{4}$ fractionation, gel filtration through sephadex G-100 and DEAE-cellulose ion exchange chromatography was use, The purity was checked by native PAGE while subunit by SDS PAGE

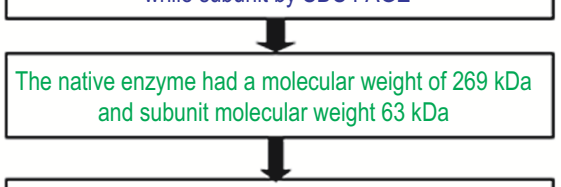

Optimum activity at $37^{\circ} \mathrm{C}$ thermostable upto $50^{\circ} \mathrm{C}$ at $\mathrm{pH} 6.5$.

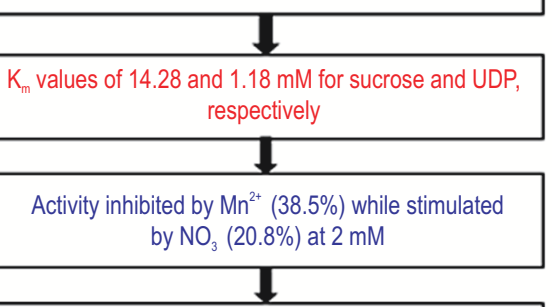

The enzyme was highly specific for UDP as substrate and NADP and G-6-P were found to be the potent inhibitors

Sucrose synthase catalyzed the sucrose degradation by ping-pong mechanism revealed by kinetic studies 


\section{Introduction}

Wheat is an important cereal crop due to its unique physio-chemical and nutritional properties that makes it irreplaceable staple food in the daily diet of modern man. Its production area is very wide of about 221.70 million ha with annual production of 659.9 million tonnes within a wide range of environments, which explains its huge involvement in human life around the whole world (FAO, 2015). However, wheat production and quality is greatly affected by climatic changes at either germination, growing or maturation stage that in turn directly affects the nutrition properties and quality of end products. From past few years the increased terminal heat stress has lead to terrible loss of crop productivity (Bita and Gerats, 2013) as cooling period for wheat is constantly reducing and high temperature beyond $30^{\circ} \mathrm{C}$, which is usually encountered during later part of grain filling period, drastically reduces the yield and quality (Singh etal., 2011; Zhao etal., 2011).

The developing grains are active sites for the synthesis of a wide range of necessary metabolites and macromolecules such as starch and proteins that are essential for plant growth. Study of different level of sugar under various stresses play a crucial role in conferring the tolerance to plants by modulating several physiological processes (Rathinasabapathi, 2000; Sami et al., 2016). Starch synthesis is one of the important process that is greatly offended by this high temperature chiefly after anthesis that leads to overall reduction in grain size (Tian et al., 2006). Starch is the principal storage form of carbohydrates that forms about 70 to $85 \%$ of final dry weight of grain. Sucrose is the precursor of starch along with being the main mobile form for photosynthetic assimilates from leaves to endosperm. The ability of plant to transport sucrose is significantly correlated with temperature as unfavorable temperature can potential reduces crop productivity (Fitz Simons and Oosterhuis, 2016). Sucrose metabolism is one of the crucial processes as it is essential for the distribution of crucial carbon resources and for the initiation of various signals involving hexose based sugar signals (Koch, 2004). Sucrose synthase (UDP glucose: D-fructose-2-glucosyl transferase, EC 2.4.1.13) is the first and most important enzyme that catalyzes the first metabolic step in sucrose-starch conversion pathway, which catalyzes the reversible interconversion of sucrose and UDP to UDP-glucose and fructose (Baroja-Fernández et al., 2003; Keeling and Myers, 2010). But sucrose synthase mainly contributes in the direction of sucrose degradation to provide sugar nucleotides for complex polymers synthesis (Chourney, 1981; Volpicella et al., 2016).

The relationship between source and sink decides the yield of a crop. As it is highly active in growing sink organ, so can act as a marker for sink strength (Jie et al., 2012). The characterization of this important interconversions between sucrose and starch in sink organs of thermotolerant wheat is very important and this prerequisite the detailed knowledge of the sucrose synthase. Hence, the aim of the present study was to purify sucrose synthase from thermotolerant wheat and further characterize it for molecular weight, effect of temperature, $\mathrm{pH}$, substrate concentration, ions and inhibitors.

\section{Materials and Methods}

Plant material : The immature grains (21 Days after anthesis) of thermotolerant wheat $\mathrm{WH}-1021$ were harvested from the field of Wheat Section of the Department of Plant Breeding, CCS Haryana Agricultural University, Hisar. All the chemicals and biochemicals were of high purity analytical grade.

Extraction of sucrose synthase : Extraction of enzyme was as per the method described by Sharma and Chugh (2017) using ammonium fractionation (30-60\%), column (sephadex G-100) and ion exchange chromatography (DEAE- cellulose) techniques.

Enzyme assay : Sucrose synthase activity in crude extract and in the preparations during purification process was assayed by the method of Shannon and Dougherty (1972). The reaction mixture $(1 \mathrm{ml})$ that contain UDP (One $\mu$ mole), sucrose $(25 \mu$ moles $)$ and MES buffer ( $\mathrm{pH} 6.5,60 \mu$ moles) and enzyme preparation was incubated for $15 \mathrm{~min}$ at $37^{\circ} \mathrm{C}$. The reaction was terminated by placing the reaction mixture in boiling water bath for $2 \mathrm{~min}$. Released fructose was measured by Somogyi's modified method (Somogyi, 1945). The equivalent amount of fructose was calculated from a standard curve prepared by using glucose (200 $\left.\mu \mathrm{g} \mathrm{ml}^{-1}\right)$. One unit of enzyme is defined as the amount of enzyme that catalyses the formation of one $\mu$ mole of product per hour.

Protein estimation : Protein in various fractions during purification was detected by measuring the extinction at $280 \mathrm{~nm}$. Quantitative estimation of protein at each step of purification, however, was done by following the method of Lowry et al. (1951).

Characterization of sucrose synthase : The molecular weight of purified enzyme was estimated through Sephadex G-100. The column was calibrated with the following standard protein markers (2 $\mathrm{mg} \mathrm{ml}^{-1}$ each): cytochrome-C (12.4 kDa), carbonic anhydrase $(29.0 \mathrm{kDa})$, bovine serum albumin $(66 \mathrm{kDa})$, alcohol dehydrogenase (150 kDa) and $\beta$-Amylase (200 kDa). The void volume was calculated by using blue dextran. The log molecular weight of each standard protein was plotted against elution volume and the molecular weight of purified enzyme was calculated from the calibration graph. Subunit molecular weight was determined by carrying out polyacrylamide gel electrophoresis $(10 \%$ gel) in the presence of SDS following the method of Laemmili (1970).

The purity of enzyme preparation was checked by nativePAGE using anionic system of Davis (1964). Different buffers of different $\mathrm{pH}$ values were used viz. for $\mathrm{pH}$ range 4.0-5.6, $0.06 \mathrm{M}$ acetate buffer, for $\mathrm{pH}$ range 5.7-6.7, $0.06 \mathrm{M} \mathrm{MES} \mathrm{buffer,} \mathrm{for} \mathrm{pH}$ range 5.8-7.2, $0.06 \mathrm{M}$ phosphate buffer and for $\mathrm{pH}$ range 7.3-8.0, 
$0.06 \mathrm{M}$ tris- $\mathrm{HCl}$ buffer and $\mathrm{pH}$ at which maximum activity was observed was taken as $\mathrm{pH}$ optima. The effect of temperature on the purified enzyme activity was evaluated at temperature ranging from 25 to $65^{\circ} \mathrm{C}$. Except for the enzyme, all constituents of the reaction mixture were maintained at appropriate temperature in a water bath before starting the reaction. Thermostability of purified enzyme was tested by measuring the residual activity after incubating the enzyme for $30 \mathrm{~min}$ at temperature ranging from 25 to $65^{\circ} \mathrm{C}$. The substrate specificity of enzyme sucrose synthase was determined by incubating different potential nucleotide substrates viz. UDP, ADP, CDP, TDP and GDP at a concentration of $1 \mathrm{mM}$ with the enzyme at a saturating concentration of sucrose $(25 \mathrm{mM})$. Activity was calculated by taking activity of control as $100 \%$.

The activity of purified preparation was measured using UDP as substrate at a final concentration varying from 0.2 to 1.8 $\mathrm{mM}$ and at a constant concentration of sucrose $(25 \mathrm{mM})$ and similarly using sucrose as substrate at a final concentration varying from 5 to $45 \mathrm{mM}$ and at a constant concentration of UDP (1 $\mathrm{mM})$. The $\mathrm{K}_{\mathrm{m}}$ values were determined by using the Lineweaver-Burk plot method (1934). The mechanism of bisubstrate reaction catalyzed by purified enzyme was investigated by incubating the enzyme with saturating and subsaturating concentrations of one substrate and varying the concentration of the other substrate.

The activity of purified preparation was measured in the presence of different metabolites at three different concentrations (1,2 and $5 \mathrm{mM})$. The percentage of stimulation and inhibition was expressed as relative to the enzyme activity without inhibitor. The effects of monovalent $\mathrm{Na}^{+}, \mathrm{K}^{+}, \mathrm{Cl}^{-}, \mathrm{HCO}_{3}^{-}$, $\mathrm{CH}_{3} \mathrm{COO}$ and $\mathrm{NO}_{3}^{-}$; divalent $\mathrm{Ca}^{2+}, \mathrm{Mn}^{2+}, \mathrm{Mg}^{2+}, \mathrm{CO}_{3}^{2-}$ and $\mathrm{SO}_{4}^{2-}$ ions were determined by carrying out enzyme assay at $2 \mathrm{mM}$ concentration of these metal ions. Residual activity was calculated taking activity of control as $100 \%$.

\section{Results and Discussion}

Sucrose synthase from wheat grains was purified through a traditional four-step purification procedure. The specific activity in crude extract and $\left(\mathrm{NH}_{4}\right)_{2} \mathrm{SO}_{4}$ fraction was 10.11 and 32.20 units $\mathrm{mg}^{-1}$ protein $(30-60 \%)$, respectively (Table 1 ) with 3.18 fold purification. In further purification by molecular exclusion and ion exchange chromatography through Sephadex G-100 and DEAEcellulose, about 27 fold purity was obtained with approximately $37 \%$ recovery. Sytykiewicz et al. (2008) also reported a 21 -fold purification of sucrose syntahse through the Sephadex G-150 and DEAE-cellulose column, in cherry leaves. In DEAE cellulose column the enzyme elution was carried out with $0.1-0.5 \mathrm{M} \mathrm{NaCl}$ gradient in $30 \mathrm{mM}$ tris- $\mathrm{HCl}$ buffer ( $\mathrm{pH} 7.5)$, which illustrates the anionic nature of the enzyme. The final enzyme preparation had specific activity of 270.41 units $\mathrm{mg}^{-1}$ protein, which is comparable to that reported for sucrose synthase from wheat grains (Anand and Singh, 1986).

The molecular weight of purified sucrose synthase as determined from gel filtration through sephadex G-100 column was $269 \mathrm{kDa}$ (Fig. 1 and 2A), which was in accordance with the molecular weight calculated by the equation proposed by Squire

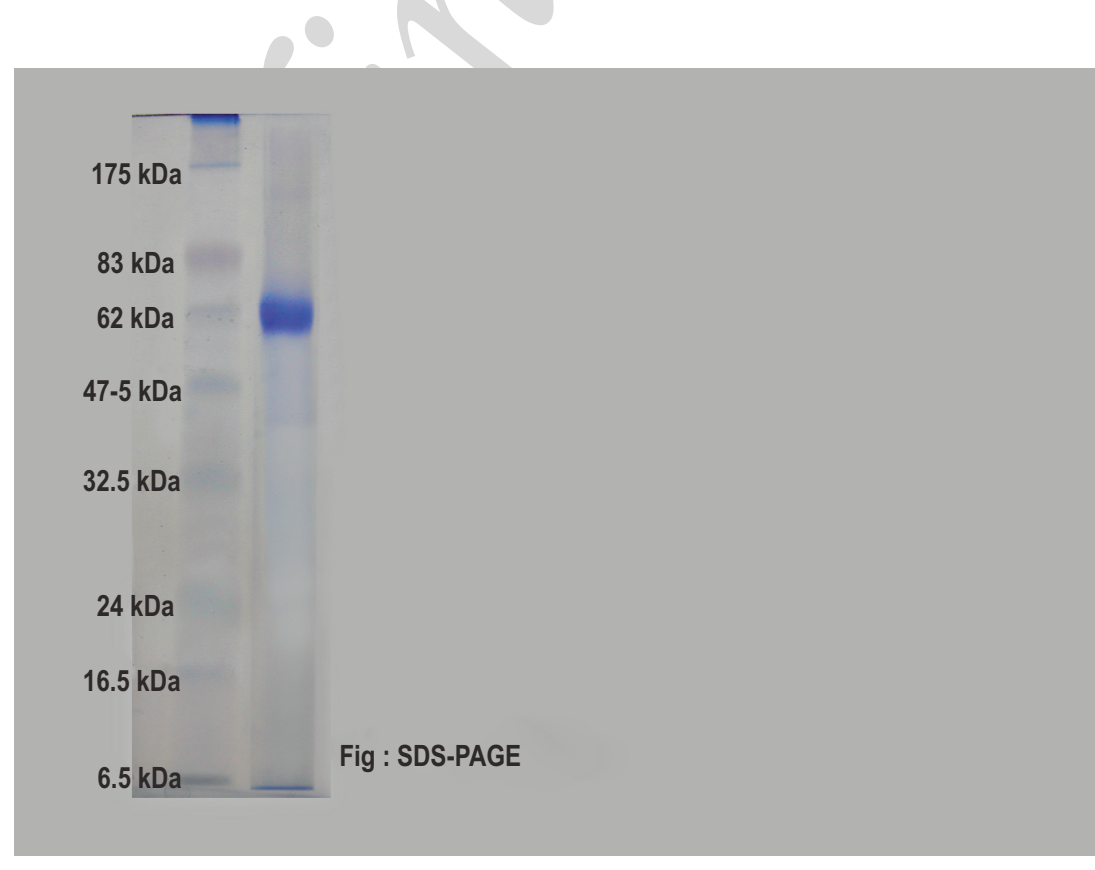

Fig. 1 : SDS-PAGE pattern of purified sucrose synthase from wheat grains 
Table 1: Summary of purification of sucrose synthase from immature wheat grains

\begin{tabular}{lllllll}
\hline Fraction & $\begin{array}{l}\text { Volume } \\
(\mathbf{m l})\end{array}$ & $\begin{array}{l}\text { Total activity } \\
\text { (Units) }\end{array}$ & $\begin{array}{l}\text { Protein } \\
(\mathbf{m g})\end{array}$ & $\begin{array}{l}\text { Specific activity } \\
\text { (Units/mg } \text { protein) }\end{array}$ & $\begin{array}{l}\text { Fold } \\
\text { purification }\end{array}$ & $\begin{array}{l}\text { Recovery } \\
(\%)\end{array}$ \\
\hline Crude extract & 315 & 4200.00 & 415.30 & 10.11 & - & 100 \\
$\left(\mathrm{NH}_{4}\right)_{2} \mathrm{SO}_{4}(30-60 \%)$ & 20 & 3438.60 & 106.80 & 32.20 & 3.18 & 81.19 \\
Sephadex G-100 & 33 & 2773.16 & 15.88 & 174.63 & 17.26 & 66.03 \\
DEAE-cellulose & 60 & 1541.32 & 5.7 & 270.41 & 26.72 & 36.70 \\
\hline
\end{tabular}

Table 2 : Substrate specificity of sucrose synthase

\begin{tabular}{lll}
\hline Substrate & Concentration $(\mathrm{mM})$ & Enzyme activity (\% control) \\
\hline UDP & 1 & 100 \\
ADP & 1 & 34 \\
TDP & 1 & 12 \\
CDP & 1 & 21 \\
GDP & 1 & 3 \\
\hline
\end{tabular}

Table 3 : Effect of various metabolites on purified sucrose synthase

\begin{tabular}{|c|c|c|c|}
\hline \multirow[t]{2}{*}{ Metabolites } & \multicolumn{3}{|c|}{ Enzyme activity ( $\%$ of control) } \\
\hline & $1 \mathrm{mM}$ & $2 \mathrm{mM}$ & $5 \mathrm{mM}$ \\
\hline AMP & 100.0 & 102.9 & 73.7 \\
\hline ADP & 103.6 & 100.0 & 88.4 \\
\hline ATP & 100.9 & 100.0 & 100.0 \\
\hline ADPG & 103.5 & 99.4 & 100.0 \\
\hline $\mathrm{NAD+}$ & 99.3 & 101.3 & 101.9 \\
\hline NADH & 100.0 & 100.4 & 101.2 \\
\hline NADP+ & 99.7 & 95.9 & 84.1 \\
\hline NADPH & 100.0 & 99.6 & 99.2 \\
\hline G-1-P & 102.5 & 101.0 & 100.0 \\
\hline G-6-P & 100.8 & 86.6 & 66.4 \\
\hline \multicolumn{4}{|c|}{ Table 4 : Effect of various metal ions on purified sucrose synthase } \\
\hline $\begin{array}{l}\text { lons } \\
(2 \mathrm{mM})\end{array}$ & $\begin{array}{l}\text { Enzyme activity } \\
\text { ( } \% \text { control) }\end{array}$ & $\begin{array}{l}\text { Stimulation } \\
(\%)\end{array}$ & $\begin{array}{l}\text { Inhibition } \\
(\%)\end{array}$ \\
\hline \multicolumn{4}{|l|}{ Control } \\
\hline & 111.9 & 11.9 & - \\
\hline $\mathrm{Na}^{+}$ & 109.7 & 9.7 & - \\
\hline $\mathrm{Mn}^{2+}$ & 61.5 & - & 38.5 \\
\hline $\mathrm{Mg}^{2+}$ & 84.5 & - & 15.5 \\
\hline $\mathrm{Ca}^{2+}$ & 98.7 & - & 01.3 \\
\hline $\mathrm{Cl}^{-}$ & 98.7 & - & 01.3 \\
\hline $\mathrm{HCO}_{3}^{-}$ & 112.9 & 12.9 & - \\
\hline $\mathrm{CH}_{3} \mathrm{COO}$ & 83.9 & - & 16.1 \\
\hline $\mathrm{NO}_{3}^{\circ}$ & 120.8 & 20.8 & - \\
\hline $\mathrm{CO}_{3}^{2 \cdot}$ & 109.9 & 9.9 & - \\
\hline
\end{tabular}

(1964). The subunit molecular weight, as determined by SDSPAGE, was estimated to be $63 \mathrm{kDa}$ (Fig. 2B), indicating the tetrameric configuration of sucrose synthase and single band on SDS-PAGE suggested the homomeric structure of sucrose synthase. The homomeric structure is generally connected with high stability of enzyme, which is turn is prerequisite for the proper functioning of the enzyme (Bergandahi and Marsh, 2017).The sucrose synthase purified from rice was homooctameric enzyme 

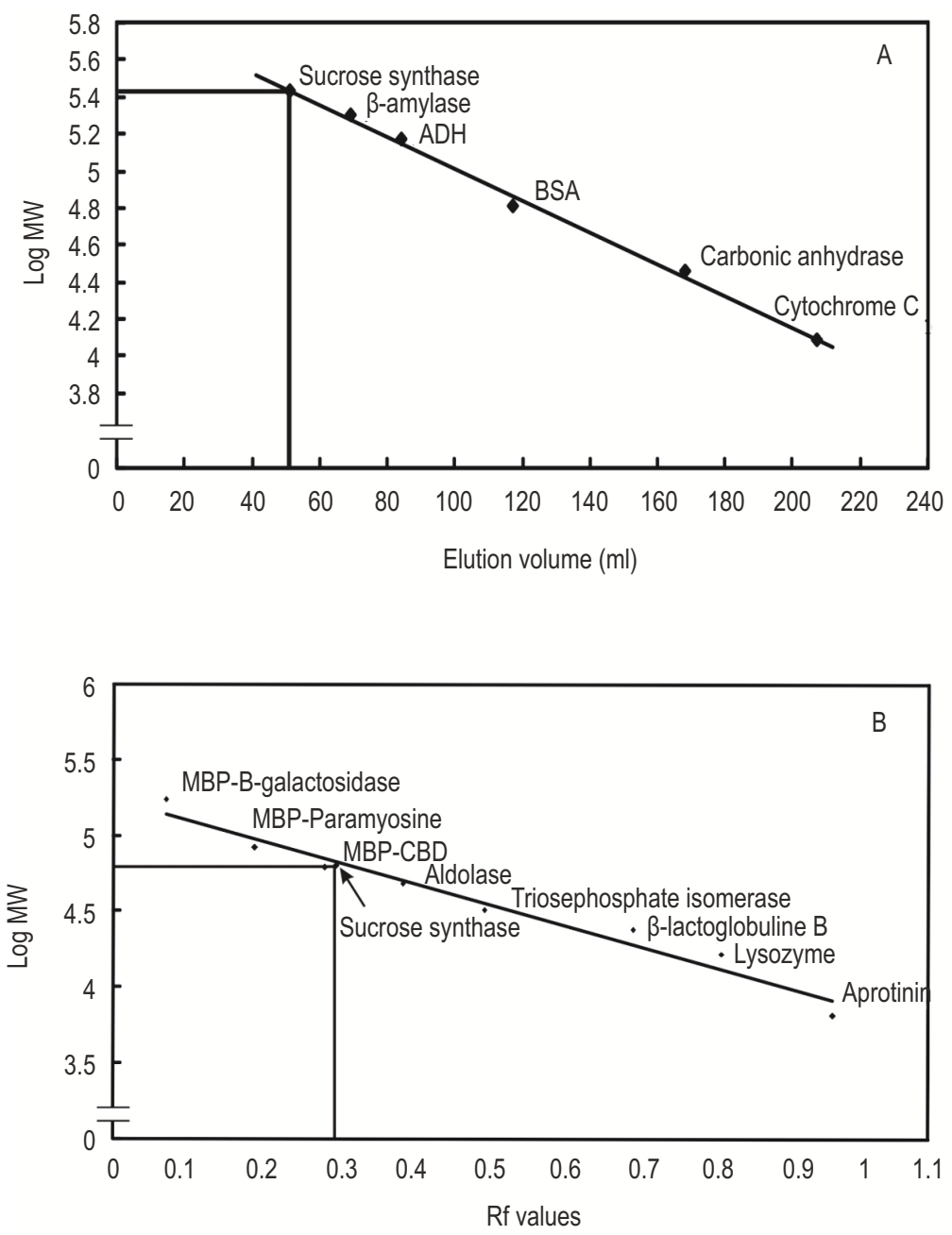

Fig. 2 : Determination of molecular weight of purified sucrose synthase through A- Sephadex G-100, B- SDS-PAGE

from rice grains with molecular weight $235 \mathrm{kDa}$ (Singal et al., 2009) The variations reported in the observed molecular weight values may be due to different methods employed for these determinations and different plant species used.

The environment surrounding the enzyme is essential for its stability and function. The enzyme activity as determined over a range of $\mathrm{pH} 4.0-8.0$ (Fig. $3 \mathrm{~A}$ ) increased from 84.77 Units $\mathrm{mg}^{-1}$ protein to 270.25 Units $\mathrm{mg}^{-1}$ protein at $\mathrm{pH} 4.0$ and 6.5, respectively. Thereafter, enzyme activity decreased which clearly indicates that $\mathrm{pH} 6.5$ is optimum purified sucrose synthase. This $\mathrm{pH}$ value is in conformity with the report for the enzyme from rice grains (Singal et al., 2009), which has $\mathrm{pH}$ optima of 6.5 in the direction of UDP-glucose synthesis. The difference observed has been related to some conformational changes in enzyme, which alter its kinetic properties.
The sucrose synthase showed maximum activity at $37^{\circ} \mathrm{C}$ and lesser activity above and below this temperature (Fig. 3B). The enzyme purified during the present investigation was stable upto $50^{\circ} \mathrm{C}$ over a pre-incubation period of $30 \mathrm{~min}$, and at higher temperature, the enzyme underwent rapid inactivation (Fig. 2C). At $65^{\circ} \mathrm{C}$, the enzyme lost $75 \%$ of its activity. Similarly, the enzyme purified from tomato (Sun et al., 1992), rice grains (Elling and Kula, 1995) and sugar beet (Klotz et al., 2003) had thermostability between $50-60^{\circ} \mathrm{C}$. The loss in the activity above the temperature range could be due to distortion of 3-D native structure of the enzyme.

Out of all different nucleotide substrates tested at $1 \mathrm{mM}$ concentration and saturating concentration of sucrose $(25 \mathrm{mM})$, sucrose synthase activity was highest with UDP (Table 2). None of the other nucleoside diphosphate tested was as active as UDP, 

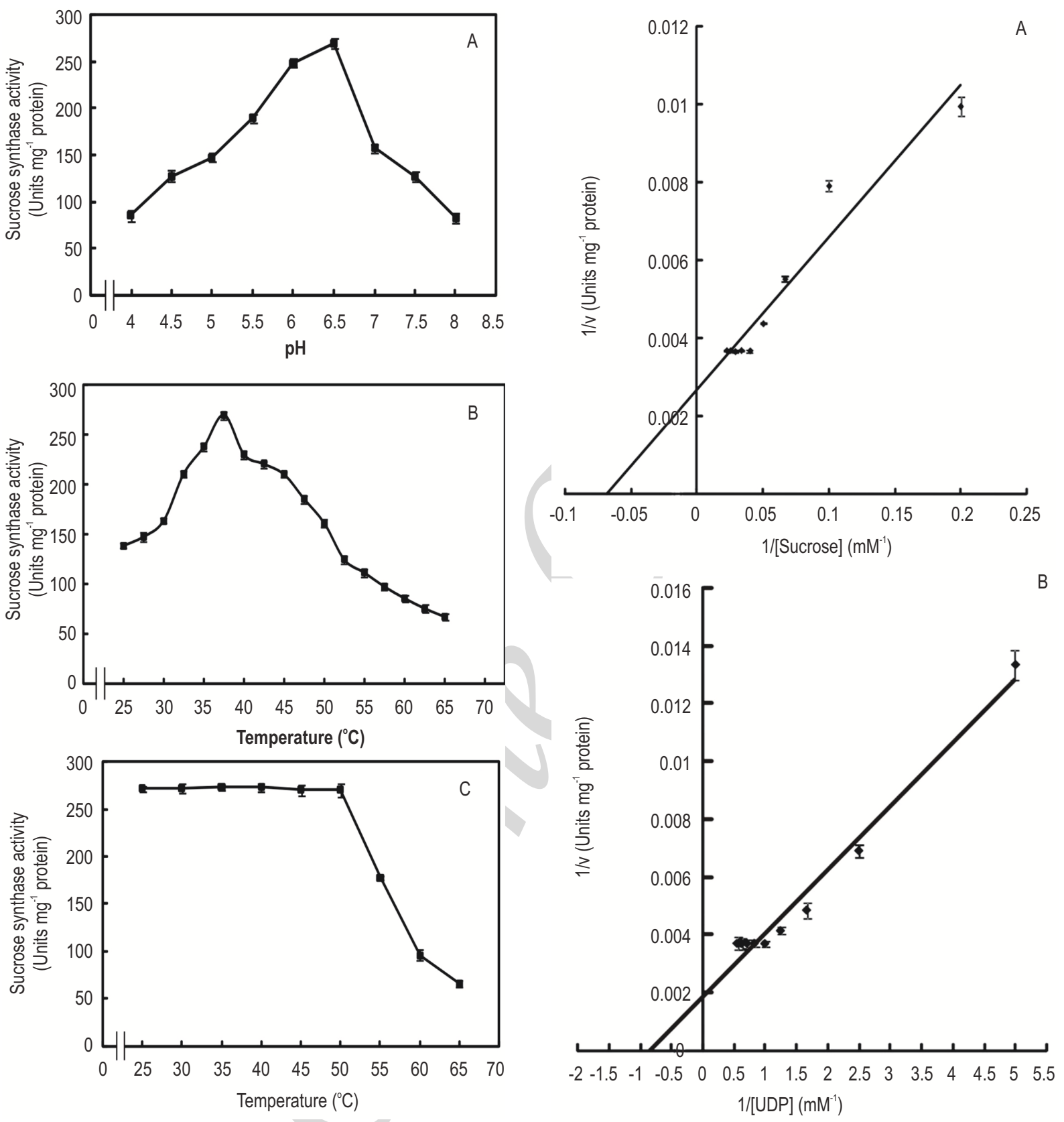

Fig. 3 : (A) pH Activity profile, (B) Temperature activity profile and (C) Temperature stability of purified sucrose synthase from wheat grains. Values are mean of three replicates \pm SD from triplicate determinations

which is in consistent with earlier reports for the enzyme from wheat and rice grains (Huang and Wang, 1998; Singal et al., 2009), showing higher affinity of enzyme for UDP as substrate. Although, ADP specific sucrose synthase have also been reported from spinach leaves (Pozueta-Romero et al., 1991).

Fig. 4 : (A) Determination of Michaelis-Menten constant $\left(K_{m}\right)$ for purified sucrose synthase as a function of sucrose concentration and (B) UDP concentration

Sucrose synthase followed typical Michaelis-Menten kinetics with $\mathrm{K}_{\mathrm{m}}$ values of $14.28 \mathrm{mM}$ for sucrose (Fig. 4A) and 1.18 $\mathrm{mM}$ for UDP (Fig. 4B). Similar, hyperbolic saturation curves and high $\mathrm{Km}$ values for sucrose have been reported for the enzyme purified from wheat and barley (Martinez et al., 1993). The 

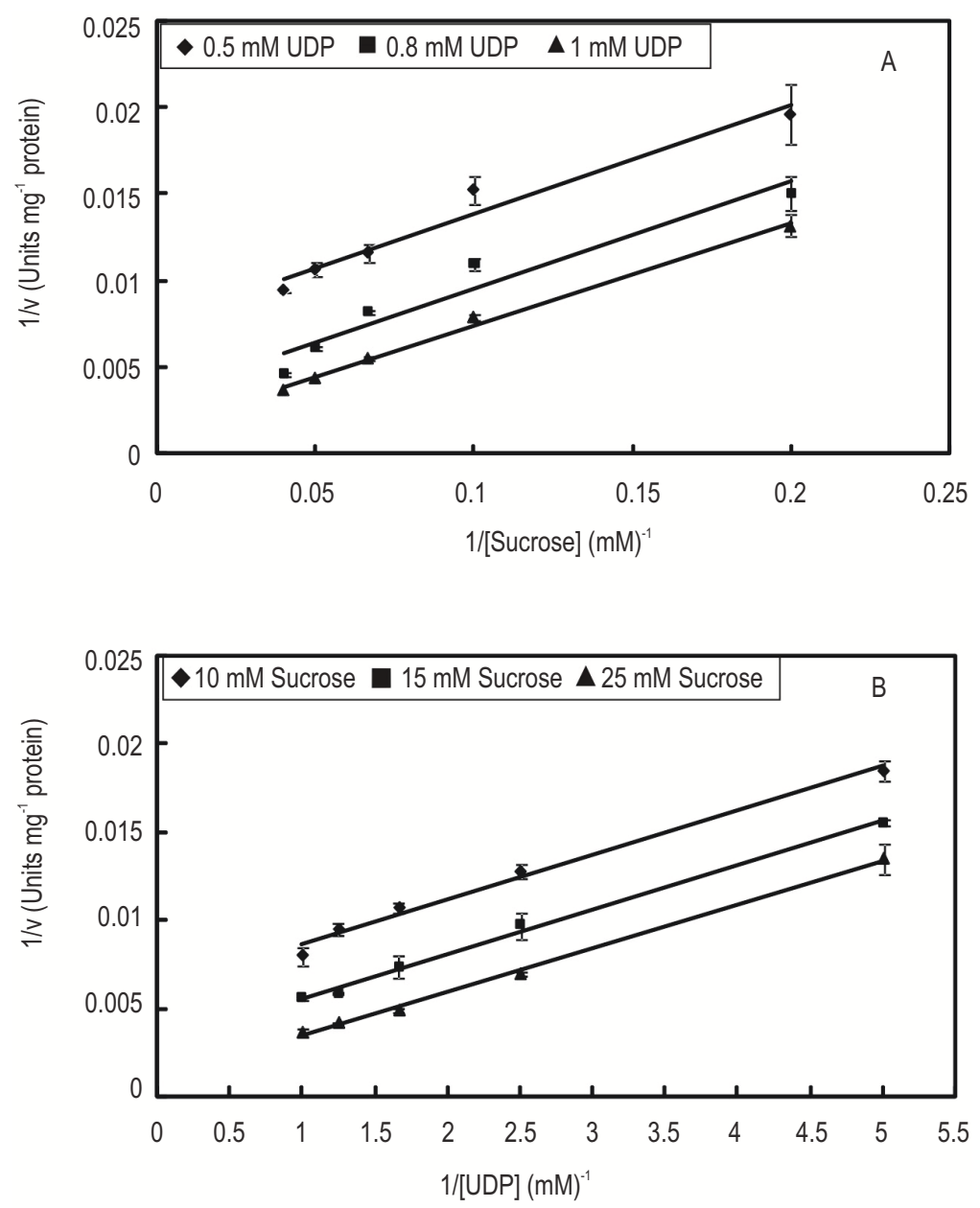

Fig. 5 : Effect of varying concentration of sucrose and UDP on sucrose synthase activity in the resence of three different concentration of UDP (A) and sucrose $(B)$. Values are mean of three replications \pm SD

effectiveness of sucrose cleavage reaction prominent at a higher concentration of sucrose and UDP is characteristic of developing grains. A plot of reciprocal concentrations of UDP vs reciprocal of reaction rates at fixed sub-saturating $(10 \mathrm{mM}$ and $15 \mathrm{mM})$ and saturating $(25 \mathrm{mM})$ concentrations of sucrose gave a set of parallel lines (Fig. 5A), indicating that the enzyme follows ping-pong type of bisubstrate-biproduct mechanism. Similarly, a double reciprocal plot of sucrose concentrations vs reaction rates at sub-saturating ( $0.5 \mathrm{mM}$ and $0.8 \mathrm{mM})$ and saturating $(1 \mathrm{mM})$ concentration of UDP again gave a set of parallel lines (Fig. 5B), confirming the view that the enzyme follows ping-pong mechanism.

The effect of various metabolites was studied on sucrose synthase activity. The results presented in Table 3 indicate that the enzyme activity was negligibly affected by metabolites at low concentration (1 mM). At 5 mM concentration AMP, ADP, NADP ${ }^{+}$ and G-6-P inhibited the enzyme activity by approximately 26,12 , 16 and $34 \%$, respectively. NADP ${ }^{+}$and G-6-P also inhibited the enzyme activity by about 4 and $13 \%$ at $2 \mathrm{mM}$ concentration. Similar result for NAD+, NADPH and G-1-P has also been found in soybean (Morell and Copeland, 1985). The activity of this enzyme in vivo, therefore, is more likely to be controlled by substrate availability than by other type of allosteric modulation.

The effect of various metal ions on sucrose synthase activity was studied by incubating the various cations and anions at a concentration of $2 \mathrm{mM}$ each at pH 6.5 (Table 4). $\mathrm{Mn}^{2+}, \mathrm{Mg}^{2+}, \mathrm{CH}_{3} \mathrm{COO}$ - and $\mathrm{SO}_{4}^{2-}$ were found to be potent inhibitors, whereas, $\mathrm{K}^{+}, \mathrm{Na}^{+}, \mathrm{HCO}_{3}{ }^{-}, \mathrm{NO}_{3}^{-}$and $\mathrm{CO}_{3}^{-}$stimulated the enzyme activity. No particular effect of $\mathrm{Ca}^{2+}$ and $\mathrm{Cl}$ - ions was observed on stimulation or inhibition of enzyme activity. The results compare well with the finding that has been reported for 
sucrose synthase in cleaving direction (Tanase and Yamaki, 2000; Bruskova et al., 2009).

In the present study the purified sucrose synthase catalysed the sucrose cleavge by ping-pong mechanism with high specificity for UDP as substrate. Its activity is enhanced by metal ions such as $\mathrm{K}^{+}, \mathrm{Na}^{+}, \mathrm{HCO}_{3}^{-}, \mathrm{CO}_{3}$ and with maximum enhancement by $\mathrm{NO}_{3}$, which represents the use of these metal ions for regulating the enzyme activity. The present study might help in understanding the function and properties of sucrose synthase that in turn would be beneficial for crop productivity in stress and signaling.

\section{Acknowledgment}

Ekta Verma thanks CCS Haryana Agricultural University, Hisar (India) for providing financial assistance in the form of merit scholarship.

\section{References}

Anand, S. and R. Singh: Sucrose synthase from immature wheat grains. J. Plant. Sci. Res., 2, 1-10 (1986).

Baroja-Fernández, E., F.J. Muñoz, T. Saikusa, M. Rodríguez-López, T. Akazawa and J. Pozueta-Romero: Sucrose synthase catalyzes the de novo production of ADPglucose linked to starch biosynthesis in hetrotrophic tissues of plants. Plant. Cell Phys., 44, 500-509 (2003).

Bergandahi, L.T. and J.A. Marsh: Functional determinants of protein assembly into homomeric complexes. Sci. Rep., 7, 4932-4936 (2017).

Bita, C.E. and T. Gerats: Plant tolerance to high temperature in a changing environment: Scientific fundamentals and production of heat stress-tolerant crops. Front. Plant. Sci., 273, 1-18 (2013).

Bruskova, R.K., A.V. Nikitin, M.V. Satskaya and S.F. Izmailov: Effect of nitrate on pea sucrose synthase. Russ. J. Plant. Phy., 56, 74-79 (2009).

Chourey, P.: Genetic control of sucrose synthase in maize endosperm. Mol. Gen. Genet., 184, 372-376 (1981).

Davis, B.J.: Disc electrophoresis II. Method and application to human serum proteins. Ann. N. Y. Acad. Sci., 121, 404-427 (1964).

Elling, L. and M.R. Kula: Characterization of sucrose synthase from rice grains for the enzymatic synthesis of UDP and TDP-glucose. Enz. Microb. Tech., 17, 929-934 (1995).

FAO.: http://www.fao.org/docrop/0 11 /ai482e/ai482e03 .htm (2015)

FitzSimons, T.R. and D.M Oosterhuis .: The Role of temperature on the diurnal sucrose source to sink balance. J.Cotton Sci., 20,196-206 (2016)

Huang, D.Y. and A.Y. Wang: Purification and characterization of sucrose synthase isozymes from etiolated rice seedlings. Biochem. Mol. Biol. Int,. 46, 107-113 (1998).

Jie, Z., J. Xiaodong, L. Tianlai and Y. Zaiqiang: Effect of moderately-high temperature stress on photosynthesis and carbohydrate metabolism in tomato (Lycopersico esculentum L.) leaves. Afr. J. Agric. Res., 7, 487-492 (2012).

Keeling, P.L. and A.M. Myers: Biochemistry and genetics of starch synthesis. Annu. Rev. Food Sci. Technol., 1, 271-303 (2010).

Klotz, K.L., F.L. Finger and W.L. Shelver: Characterization of two sucrose synthase isoforms in sugarbeet root. Plant Phy. Biochem., 41, 107-
115(2003).

Laemmili, U.K.: Cleavage of structural proteins during the assembly of head of bacteriophage $\mathrm{T}_{4}$. Nature, 277, 680-685 (1970).

Lineweaver, $H$. and $D$. Burk :The determination of enzyme dissociation constants. J.Amer. Chem. Soc., 56, 658-666 (1934).

Lowry, O.H., N.J. Rosenbrough, A.L. Farr and J.L. Randall: Protein measurement with Folin-phenol reagent. J. Bio. Chem., 193, 265275(1951)

Martinez, D.I.O., J. Vicente-Canbajosa, I.D. Sanchez De Hoz and P. Carbonero: Sucrose synthase gene in barley. cDNA cloning of Ss2 type and tissue specific expression of Ss1and Ss2. FEBS Letters, 320, 177-181 (1993)

Morell, M. and L. Copeland: Sucrose synthase of soybean nodules. Plant Phy., 78, 149-154 (1985).

Pozueta-Romero, J., J. Yamaguchi and T. Akazawa: ADPG formation by the ADP-specific cleavage of sucrose-reassessment of sucrose synthase. FEBS Letters, 291, 233-237 (1991).

Rathinasabapathi, B.: Metabolic engineering for stress tolerance: installing osmoprotectant synthesis pathways. Ann. Bot., 86, 709$716(2000)$

Sharma, B. and L.K. Chugh: Two isoforms of lipoxygenase from mature grains of pearl millet [Pennisetum glaucum (L.) R. Br.]: Purification and physico- chemico-kinetic characterization. J. Food Sci. Tech., doi : 10/1007/s13197-017-2589-5(2017)

Shannon, J.C. and C.T. Dougherty: Movement of ${ }^{14} \mathrm{C}$ labeled assimilates into kernels of Zea mays L. II. Invertase activity of the pedicel and placento-chalazal tissues. Plant Phys., 49, 203-206 (1972).

Singal, P., A. Sindhu, K.S. Nehra and H.R. Singal: Partial purification and characterization of sucrose synthase from immature rice (Oryza sativa L.) grains. Res. Crops., 10, 743-747 (2009).

Singh, K., S.N. Sharma and S. Yogendra: Effect of high temperature on yield attributing traits in bread wheat. Bangla. J. Agric. Res., 36, 415-426 (2011).

Somogyi, M.: A new reagent for the determination of sugar. J. Biol. Chem., 160, 61-69 (1945).

Squire, P.G.: A relationship between the molecular weights of macromolecules and their elution volumes based on a model for sephadex gel filtration. Archives Biochem. Biophy., 107, 471-478 (1964).

Sun, J., T. Loboda, S.J.S. Sung and C.C. Black: Sucrose synthase in wild tomato, Lycopersicon chemielewskii and tomato fruit sink strength. Plant Phy., 98, 1163-1169 (1992).

Sytykiewicz, H., P. Czerniewicz and B. Leszczyński: Molecular characteristics of sucrose synthase isolated from bird cherry leaves. Herba Polo., 54, 41-49 (2008).

Sami, F., M. Yusuf, M. Faizan, A. Faraz and S. Hayat: Role of sugars under abiotic stress. Plant Phy. Biochem.,109, 54-61 (2016)

Tanase, K. and S. Yamaki : Purification and characterization of two sucrose synthase isoforms from Japanese pear fruit. Plant Cell Phy., 41, 408-414 (2000).

Tian, L., L.Q. Hua, R. Ohsugi, T. Yamagishi and H. Sasaki: Effect of high temperature on sucrose content and sucrose-cleaving enzymes activity in rice during grain filling stage. Zhon. Shuidao Kexue,. 20, 626-630 (2006).

Volpicella, M., I. fanizza, C. Leoni, A. Gadaleta, D. Nigra, B. Gattulli, G. Mangini, A. Blanco and L.R. Ceci: Identification and characterization of sucrose snthase 2 gene (Sus 2) in durum wheat. Frontier in Plant Science, 10, doi.org/10.3389/fpls. 2016.00266 (2016).

Zhao, A.Q., B. Qiong-Li, T. Xiao-Hong, L. Xin-Chun and W.J. Gale: Combined effect of iron and zinc on micronutrient levels in wheat (Triticum aestivum L.). J. Env. Bio., 32, 235-239 (2011) 